\title{
Markers and Mediators of Inflammatory Response in Infection and Sepsis*
}

\section{Indicadores e Mediadores de Resposta Inflamatória na Infecção e Sepse}

\author{
Suzana Margareth Lobo', Francisco Ricardo Marques Lobo²
}

\section{RESUMO}

JUSTIFICATIVA E OBJETIVOS: A sepse é a expressão de uma complexa rede de mediadores. Falência de múltiplos órgãos e choque séptico são as principais causas de óbito nas unidades de terapia intensiva em todo o mundo. Indicadores biológicos como as citocinas, bem como centenas de outros indicadores celulares, moléculas bioativas circulantes ou produtos da coagulação são potenciais indicadores biológicos que poderão ser de grande utilidade no reconhecimento e tratamento da infecção e sepse. O objetivo deste estudo foi apresentar os principais indicadores que podem ser utilizados, atualmente ou possivelmente, no futuro, na prática clínica ou experimental.

CONTEÚDO: Revisão dirigida da literatura sobre possíveis indicadores de infecção e sepse, com ênfase aos da cascata da coagulação, proteína C-reativa e procalcitonina.

CONCLUSÕES: O papel da maioria dos indicadores biológicos não está ainda definido para uso na prática clínica. Todavia os níveis séricos de PCR e de procalcitonina podem ser de grande auxílio no diagnóstico e

1. Coordinator of the Intensive Care Unit. Associated Professor of Internal Medicine. Division of Critical Care Medicine, Department of Internal Medicine, Medical School - Hospital de Base, São José do Rio Preto, São Paulo, Brazil

2. Associated Professor of Anesthesiology. Division of Anesthesiology, Department of Surgery. Medical School - Hospital de Base, São José do Rio Preto, SP, Brazil

*Received from Hospital de Base da Faculdade de Medicina de São José do Rio Preto (FAMERP), SP

Submitted December 3, 2006

Accepted March, 2, 2007

Address correspondence:

Prof. Dra. Suzana Margareth Lobo

Avenida Brigadeiro Faria Lima, 5544

15090-000 São José do Rio Preto, SP, Brasil

E-mail: utigeral.hbase@famerp.br

(C)Associação de Medicina Intensiva Brasileira, 2007 no prognóstico da infecção e da sepse quando usados em conjunto com os parâmetros convencionais.

Unitermos: choque séptico, falência de múltiplos órgãos, indicadores, mediadores, sepse, síndrome da resposta inflamatória sistêmica.

\section{SUMMARY}

BACKGROUND AND OBJECTIVES: Sepsis is the expression of a complex network of mediators. Multiple organ dysfunction and septic shock indeed remain a major cause of death among ICU patients worldwide. Prompt recognition of both the diagnosis and the complicated evolution are essential, hence the importance of using biological markers. The main pro-inflammatory and anti-inflammatory cytokines as well as hundreds of others cellular markers, circulating bioactive molecules or coagulation products are potential biological markers that could help to characterize the presence of infection and sepsis. We aimed to review the main biological markers that could be used nowadays or possibly in the future, either in clinical or research fields.

CONTENTS: A selective review of biologic markers of sepsis focusing on markers of the coagulation cascade, C-reactive protein and procalcitonin.

CONCLUSIONS: Most of the available biological markers is still not a practical method to be used at the bed-side and is currently restricted to research works. Nowadays the determination of CRP or PCT serum levels can be of great help in the critically ill patient care along with the conventional parameters.

Key Words: markers, mediators, multiple organ dysfunction, sepsis, septic shock, systemic inflammatory response syndrome.

\section{INTRODUCTION}

It is often very difficult to distinguish infection, which is a microbiological process, from sepsis that is the host reaction to this process. As many as 1 million patients 
develop severe sepsis annually in US and more than 300,000 require organ support ${ }^{1}$. Septic shock indeed remains a major cause of death. Therefore, prompt recognition of both the diagnosis and the severity of the disease are essential. The main pro-inflammatory and anti-inflammatory cytokines as well as lots of other cellular markers, bioactive circulating molecules or coagulation products are potential biological markers that could help to distinguish the presence of systemic inflammatory response syndrome (SIRS), disseminated intravascular coagulation (DIC) and sepsis². We aimed to review the main biological markers that could be used nowadays or possibly in the future, either in clinical or research fields.

\section{BIOLOGICAL MARKERS}

In a simplified way, in sepsis, the mononuclear phagocytes bind to microbial structures through receptors such as CD14 and Toll-like, signaling for the production of some mediators, dependent on the activation of nuclear factor- $\kappa \mathrm{B}$ genes ${ }^{2,3}$. Toll-like receptors (TLR) are transmembrane proteins that interact with different agents ${ }^{4}$. The most known are the TLR4 that interacts with the endotoxin; the TLR2 that interacts with the components of the cellular membrane of the gram-positive bacteria; the TLR5 whose ligand is the flagellin, the main protein component of the flagella of bacteria, and the TLR3 for the virus. Efforts have been made in understanding the signaling mechanisms of TLR. Inhibition of TLR and proinflammatory cytokine signaling highlights new ways for future treatments.

There are other receptors that recognize the lypopolysaccaride (LPS), such as CD11/CD18, $\mathrm{K}^{+}$channels and macrophage scavenger receptor. Other soluble and membrane proteins are involved in the recognition of bacteria and its products, such as protein recognition peptidoglicans and triggering receptor expressed on myeloid cells (TREM-1) ${ }^{5}$. TREM- 1 may be a potential therapeutic target for septic shock. The determination of the level of a soluble form of TREM-1 (sTREM1) released from the activated macrophages in biological fluids as plasma or bronchoalveolar lavage help to rapidly identify the presence of infection ${ }^{6}$.

Some cytokines are earlier released during the inflammatory response; interleukin-1 (IL-1) and the tumor necrosis factor- $\alpha$ (TNF). It is followed by the production of other pro-inflammatory cytokines, such as IL-6, IL-8; and anti-inflammatory, such as soluble IL-10 and its receptors (IL-2r, TNF55r and TNF75r) ${ }^{2,3}$. Both the IL-
6 and the TNF- $\alpha$ induce the synthesis of acute phase proteins, particularly C-reactive protein (CRP) and the procalcitonin $(\mathrm{PCT})^{7}$. The extreme and prolonged increase of IL-6 circulating level after trauma, burning, SIRS, sepsis and elective surgery is related to morbidity and mortality ${ }^{8,9}$. After major surgery, a raised IL-6 level in day 1 , when associated with signs of SIRS, is an early marker of sepsis ${ }^{10}$. An up-regulation of inflammatory cytokines production was reported in the earliest stage of sepsis followed by dramatic down-regulation in the phases of severe sepsis or septic shock ${ }^{11}$.

An important cytokine protein is the macrophage migration-inhibitory factor (MIF). The MIF plays a role in the modulation of immune response through TLR4 allowing the prompt macrophage response. High levels of MIF have been detected in patients with severe sepsis and septic shock and were associated with microbiologically documented sepsis after cardiac surgery ${ }^{12,13}$. Another mediator, pre-B-cell colony-enhancing factor may be required for complete expression of the thrombininduced inflammatory response and has the potential to be a novel marker of acute lung injury and endothelial barrier dysfunction ${ }^{14}$. A protein known as HMGB1 (High Mobility Group Box-1) has been described as a late mediator of inflammation and sepsis. Patients with sepsis have a high concentration of HMGB 1 up to 1 wk after admission ${ }^{15}$.

\section{COAGULATION MARKERS}

The systemic inflammation is followed by the coagulation system activation ${ }^{16}$. Figure 1 represents the interaction between inflammation and coagulation. The endothelial injury caused by LPS and pro-inflammatory cytokines stimulates the production of the tissue factor (TF). The excessive production of thrombin and its inadequate removal by the fibrinolytic system result in widespread intravascular deposition of fibrin characterizing DIC. Routine blood tests do not have the necessary specificity for DIC diagnosis ${ }^{17}$. DIC dynamics may be better evaluated by measuring markers of the coagulation activation or the secondary fibrinolysis, such as prothrombin fragment $1+2(\mathrm{~F} 1+2)$, antithrombin (AT), soluble fibrin (SF), thrombin-antithrombin complex (TAT), and fibrin degradation products (FDP) ${ }^{18,19}$.

The beginning of sepsis is marked by an immediate decline in the activity of factor VIla followed by a gradual increase in the plasma levels of $\mathrm{F} 1+2$ and complex TAT; direct evidence of pro-coagulant state ${ }^{20}$. However, the specificity of $\mathrm{F} 1+2$ for $\mathrm{DIC}$ is low once the coagulation 


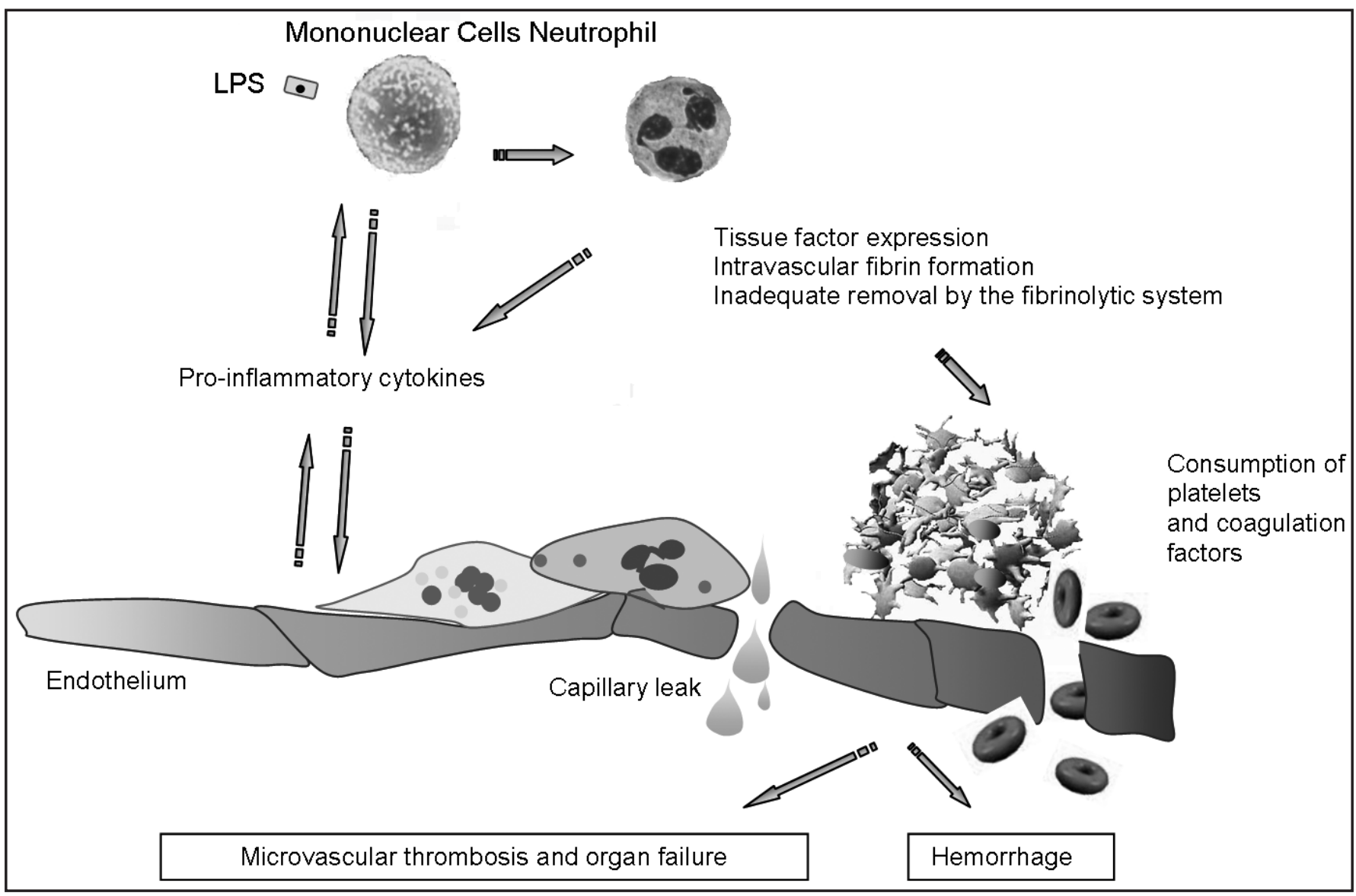

Figure 1 - Schematic Representation of the Interaction between Inflammation and Coagulation.

process can also be triggered in the extravascular space in the absence of DIC, as in trauma or pancreatitis ${ }^{21}$. The plasma levels of TAT are high in the majority of patients with sepsis even in the absence of clinical signs of DIC, and it is related to multiple organ dysfunction (MOD), shock and death ${ }^{22}$. The TAT high sensitivity can be useful to detect coagulation activation, even at slight degrees; nevertheless its specificity is limited once increased TAT serum levels can also appear in other clinical situations such as venous thromboembolism. The initial fibrin formation product will be a complex of fibrin monomer with two fibrinogen molecules that will aggregate more molecules and will become insoluble. Thus, it consists of a variety of complexes such as the fibrin-fibrinogen trimolecular complex, the fibrin-FDP complexes, the fibrin-factor XIIla complexes, and others. The SF is an indicator of continuous intravascular coagulation process once it is only produced in intravascular medium, and remains in circulation for many hours ${ }^{23}$. It was showed a high sensitivity of SF for DIC diagnosis in neurosurgical and critically ill patients ${ }^{24}$.

When fibrinogen is converted into fibrin by thrombin, a systemic fibrinolytic, plasmin, cleaves the fibrinogen/fibrin of thrombus originating its degradation products. The D-dimer is a specific test for fibrin degradation products. However, high D-dimer serum levels are also found in many clinical situations, such as deep venous thrombosis and pulmonary thromboembolism ${ }^{25}$. A negative serum test for FDP does not exclude the diagnosis of DIC. But in severe sepsis changes in D-dimer serum concentration was an independent predictor of death ${ }^{20}$. On the other hand, the plasma levels of coagulation natural inhibitors, such as AT and protein C are remarkably reduced in sepsis and septic shock with or without signs of DIC ${ }^{18,26}$. Mortality rates of $90-100 \%$ are described in surgical and septic patients after trauma with AT lower than $70 \%$ and $60 \%$, respectively ${ }^{27}$. A reduced AT serum level is a predictor of infection or complicated course in polytraumatized patients ${ }^{28}$. The presence of an AT lower than $54 \%$ in the first day of severe sepsis was an independent predictor of death ${ }^{20}$. In severe sepsis more than $80 \%$ of the patients have reduced protein $\mathrm{C}$ levels. The protein $\mathrm{C}$ plasma levels are inversely correlated to mortality ${ }^{29}$. 
Up to date, the available tests do not present the necessary specificity for their routine use. Therefore, in the absence of a gold standard the diagnosis of DIC is based on a combination of an appropriate clinical entity known to be associated with DIC, the presence of clinical manifestations, mainly organ dysfunction, and laboratory markers of deranged clotting, such as prolonged clotting times (activated partial thromboplastin time, prothrombin time), and reduced levels of fibrinogen and platelets, and if available an abnormal test for activated clotting such as fibrin degradation products ${ }^{17}$. Other more complex tests are available only in specialized laboratories.

\section{C-REACTIVE PROTEIN}

Significant rises in CRP serum concentrations are observed in invasive infections, caused by gram-positive and gram-negative bacteria, as well as systemic fungal infections even in immunodeficient patients ${ }^{30}$. In contrast, lower increases are observed in acute viral infections. The value of a single CRP measurement in the diagnosis of infection and sepsis was investigated in some studies. It has been show that CRP is an excellent infection marker in patients admitted in the emergency room with a cut-off level of $6 \mathrm{mg} / \mathrm{dL}$ (sensitivity $=67 \%$, specificity $=94 \%$ and a ROC curve of $0.88)^{29}$. On hospital admission, plasma levels of CRP have been over $5 \mathrm{mg} / \mathrm{dL}$ in all the patients with community-acquired pneumonia (CAP), and over $10 \mathrm{mg} / \mathrm{dL}$ in $75 \%{ }^{32}$. CRP serum level is the best predictor of positive cultures after aspirative bronchopneumonia and higher levels are found in patients with pneumonia than in patients with infected bronchitis ${ }^{33}$. Patients presenting maximum daily CRP variation $>4.1 \mathrm{mg} / \mathrm{dL}$ plus a CRP level $>8.7 \mathrm{mg} / \mathrm{dL}$ had an $88 \%$ risk of infection ${ }^{34}$. In the first 24 hours decreases of CRP over $20 \%$ is independently associated with survival and are indicative of infection resolution ${ }^{35,36}$.

Discrete increases in CRP serum concentrations are associated with cardiovascular disease, systemic lupus erythematosus, dermatomyositis, systemic sclerosis, graft versus host disease, and leukemia ${ }^{37,38}$. However, in response to the infection, these patients are still capable of raising their CRP, distinguishing infection from disease relapse. Significant raises are still observed in major burning, acute pancreatitis and cancer ${ }^{30}$. In these conditions the persistence of high levels has suggested a complicated course and a second increase is highly suggestive of an infectious complication.
CRP serum levels between $5-10 \mathrm{mg} / \mathrm{dL}$ have been suggested as cut-off point for diagnosis of sepsis with sensitivity ranging from $71.8 \%$ to $98.5 \%$, and specificity ranging from $47.5 \%$ to $75 \%{ }^{39,40}$. High levels of CRP can indicate an evolution with organ dysfunction. In a heterogeneous group of critically ill patients the presence of high concentrations of CRP is related to the presence of organ dysfunction, necessity of dialysis therapy, higher ICU length of stay, and high rates of infection and mortality ${ }^{41}$. Higher CRP concentrations (10 mg/dL) at admission were associated to a particularly raised mortality. A fast decrease was associated to a more favorable evolution.

The differential diagnosis between graft rejection and sepsis is frequently difficult after organ transplants. The CRP serum levels raises just after liver transplant and reaches the maximum peak in the second day. The maximum CRP levels observed in patients with graft rejection remain low in comparison with increased CRP levels in those with infectious complications ${ }^{42}$. After bone marrow transplant CRP peak was the best independent predictor of a complicated evolution ${ }^{43}$.

CRP has negative prognostic value in critically ill patients. Elderly critically ill patients who have not survived presented average CRP serum concentrations at ICU admission significantly higher than the survivors ${ }^{44}$. A good correlation was reported between CRP and two prognostic scores - MPM II (Mortality Predict Model) and APACHE III score ${ }^{45}$. The dynamic serial evaluation of CRP levels is a valuable tool in the diagnosis and follow-up of critically ill patients and can be of great help in the decision of further procedures such as culture sampling, radiology exams or the re-adequacy of antibiotic therapy.

\section{Procalcitonin}

The use of PCT as an infection marker has been studied especially in newborn and children, in whom the infection diagnosis is more difficult ${ }^{46}$. Slight increases in PCT serum concentrations occur in local bacterial and viral infections besides other conditions as uremia, cardiogenic shock, noninfectious chronic inflammatory processes and neoplastic diseases ${ }^{47}$. Important increases of PCT are observed in systemic bacterial infections, bacterial meningitis, peritonitis, and septic shock.

In a heterogeneous group of critically ill patients a cutoff point of $0.6 \mathrm{ng} / \mathrm{mL}$ for PCT was described for the diagnosis of infection ${ }^{40}$. However, in elderly patients high levels might not be indicative of infection ${ }^{48}$. A randomized trial investigating guidance of antibiotic treatment 
duration in CAP by procalcitonin test markedly reduced antibiotic exposure in patients with CAP by reducing the duration of therapy from a median of 12 to 5 days ${ }^{49}$. This finding might have enormous implications in clinical practice.

In community-acquired bacterial meningitis a significant decrease in serum PCT was associated with cure $^{50}$. PCT serum levels of $1.3 \pm 0.2 \mathrm{ng} / \mathrm{mL}, 2 \pm 0 \mathrm{ng} /$ $\mathrm{mL}, 8.7 \pm 2.5 \mathrm{ng} / \mathrm{mL}$ and $38.6 \pm 5.9 \mathrm{ng} / \mathrm{mL}$ were reported respectively for SIRS, sepsis, severe sepsis and septic shock ${ }^{47}$.

The behavior of the PCT plasma concentrations in patients with acute renal failure is still not well known. However, PCT is better related to the severity of complications in cardiac surgery and trauma patients than CRP51,52.

\section{CONCLUSION}

The dosage of the majority of the biological markers is not yet a practical method to be used. Although many markers can identify patients at risk of infection, risk of organ dysfunction, renal failure and other outcomes whether they can be used to guide clinical decisions is not yet very clear. To date sepsis remains a clinical diagnosis. Nevertheless, at the moment, either PCT or the CRP are good markers of infection and sepsis and should be used judiciously to help decisions in the critically ill patient care along with the conventional parameters. Daily, sequential measurement of inflammatory markers is of much more value to guide therapy. Particularities of the two tests should be taken into consideration. Coagulation markers and STREM-1 seem to be promising tools to help the management of sepsis.

\section{Abbreviators}

\section{TLR -Toll-like receptors}

TREM-1 - triggering receptor expressed on myeloid cells

IL - interleukin

TNF - tumor necrosis factor- $\alpha$

CRP - C-reactive protein

PCT - PCT

MIF- macrophage migration-inhibitory factor

High Mobility Group Box-1- HMGB1

TF- tissue factor

$\mathrm{F} 1+2$ - prothrombin fragment $1+2$

AT - antithrombin

SF - soluble fibrin

TAT - thrombin-antithrombin complex

FDP - fibrin degradation products

\section{REFERENCES}

01. Angus DC, Linde-Zwirble WT, Lidicker $\mathrm{J}$ et al - Epidemiology of severe sepsis in the United States: analysis of incidence, outcome, and associated costs of care. Crit Care Med, 2001;29:1303-1310.

02. Takala A, Nupponen I, Kylanpaa-Back ML et al - Markers of inflammation in sepsis. Ann Med, 2002;34:614-623.

03. Martin C, Boisson C, Haccoun $\mathrm{M}$ et al - Patterns of cytokine evolution (tumor necrosis factor-alpha and interleukin-6) after septic shock, hemorrhagic shock, and severe trauma. Crit Care Med, 1997;25:18131819.

04. Duan ZX, Zhu PF, Jiang JX - Sepsis and membrane receptors. Chin J Traumatol, 2005;8:60-64.

05. Gibot S - Clinical review: role of triggering receptor expressed on myeloid cells-1 during sepsis. Crit Care, 2005;9:485-489.

06. Gibot S, Cravoisy A, Kolopp-Sarda MN, et al - Time-course of sTREM (soluble triggering receptor expressed on myeloid cells)-1, procalcitonin, and C-reactive protein plasma concentrations during sepsis. Crit Care Med, 2005;33:792-796.

07. Baumann H, Gauldie J - The acute phase response. Immunol Today, 1994;15:74-80.

08. Biffl WL, Moore EE, Moore FA et al - Interleukin-6 in the injured patient. Marker of injury or mediator of inflammation? Ann Surg, 1996;224:647664.

09. Oda S, Hirasawa H, Shiga $\mathrm{H}$ et al - Sequential measurement of IL-6 blood levels in patients with systemic inflammatory response syndrome (SIRS)/sepsis. Cytokine, 2005;29:169-175.

10. Mokart D, Merlin M, Sannini A et al - Procalcitonin, interleukin 6 and systemic inflammatory response syndrome (SIRS): early markers of postoperative sepsis after major surgery. Br J Anaesth, 2005;94:767-773.

11. Brunialti MK, Martins PS, Barbosa de Carvalho $\mathrm{H}$ et al. TLR2, TLR4, CD14, CD11B, and CD11C expressions on monocytes surface and cytokine production in patients with sepsis, severe sepsis, and septic shock. Shock, 2006; 25:351-7

12. Bozza FA, Gomes RN, Japiassu AM et al - Macrophage migration inhibitory factor levels correlate with fatal outcome in sepsis. Shock, 2004;22:309-313

13. de Mendonca-Filho HT, Gomes GS, Nogueira PM et al - Macrophage migration inhibitory factor is associated with positive cultures in patients with sepsis after cardiac surgery. Shock, 2005;24:313-317.

14. Ye SQ, Zhang LQ, Adyshev D et al - Pre-B-cell-colony-enhancing factor is critically involved in thrombin-induced lung endothelial cell barrier dysregulation. Microvasc Res 2005;70:142-151.

15. Sunden-Cullberg J, Norrby-Teglund A, Rouhiainen A et al - Persistent elevation of high mobility group box-1 protein (HMGB1) in patients with severe sepsis and septic shock. Crit Care Med, 2005;33:564-573.

16. Levi $\mathrm{M}$, van der Poll $\mathrm{T}$, ten Cate $\mathrm{H}$ et al - The cytokine-mediated imbalance between coagulant and anticoagulant mechanisms in sepsis and endotoxemia. Eur J Clin Invest, 1997;27:3-9.

17. Taylor FB Jr, Toh CH, Hoots WK et al - Towards definition, clinical and laboratory criteria, and a scoring system for disseminated intravascular coagulation. Thromb Haemost, 2001;86:1327-1330.

18. Fourrier F, Chopin C, Goudemand J et al - Septic shock, multiple organ failure, and disseminated intravascular coagulation. Compared patterns of antithrombin III, protein $\mathrm{C}$, and protein $\mathrm{S}$ deficiencies. Chest, 1992;101:816-823.

19. Horan JT, Francis CW - Fibrin degradation products, fibrin monomer and soluble fibrin in disseminated intravascular coagulation. Semin Thromb Hemost, 2001;27:657-666.

20. Dhainaut JF, Shorr AF, Macias WL et al - Dynamic evolution of coagulopathy in the first day of severe sepsis: relationship with mortality and organ failure. Crit Care Med, 2005;33:341-348.

21. Hulka F, Mullins RJ, Frank EH - Blunt brain injury activates the coagulation process. Arch Surg, 1996;131:923-928.

22. Wilson RF, Mammen EF, Tyburski JG et al - Antithrombin levels related to infections and outcome. J Trauma, 1996;40:384-387.

23. Dempfle CE - The use of soluble fibrin in evaluating the acute and chronic hypercoagulable state. Thromb Haemost, 1999;82:673-683.

24. Bredbacka S, Blomback M, Wiman B et al - Disseminated intravascula coagulation in neurosurgical patients: diagnosis by new laboratory methods. J Neurosurg Anesthesiol, 1992;4:128-133. 


\section{MARKERS AND MEDIATORS OF INFLAMMATORY RESPONSE IN INFECTION AND SEPSIS}

25. Eisenberg PR - Does a negative D-dimer exclude trombosis? Fibrinolysis, 1993;(Suppl2):32-35.

26. Mesters RM, Helterbrand J, Utterback BG et al - Prognostic value of protein $\mathrm{C}$ concentrations in neutropenic patients at high risk of severe septic complications. Crit Care Med, 2000;28:2209-2216.

27. Wilson RF, Mammen EF, Robson MC et al - Antithrombin, prekallikrein, and fibronectin levels in surgical patients. Arch Surg, 1986;121:635640.

28. PennerJ - Antithrombin deficiency in special clinical syndromes-Part II: trauma/burns. Semin Hematol, 1995;32:(Suppl2):42-48.

29. Fijnvandraat $\mathrm{K}$, Derkx B, Peters $\mathrm{M}$ et al - Coagulation activation and tissue necrosis in meningococcal septic shock: severely reduced protein $C$ levels predict a high mortality.Thromb Haemost, 1995;73:15-20.

30. Povoa P - C-reactive protein: a valuable marker of sepsis. Intensive Care Med, 2002;28:235-243.

31. Chan YL, Tseng CP, Tsay PK et al - Procalcitonin as a marker of bacterial infection in the emergency department: an observacional study. Crit Care, 2004;8:R12-R20.

32. Smith RP, Lipworth BJ, Cree IA et al - C-reactive protein. A clinical marker in community-acquired pneumonia. Chest, 1995;108:1288-1291.

33. Adnet F, Borron SW, Vicaut E et al - Value of C-reactive protein in the detection of bacterial contamination at the time of presentation in druginduced aspiration pneumonia. Chest, 1997;112:466-471.

34. Povoa P, Coelho L, Almeida E et al - Early identification of intensive care unit-acquired infections with daily monitoring of $\mathrm{C}$-reactive protein: a prospective observational study. Crit Care, 2006;10:R63.

35. Rezende Jr DC, Moraes JMMF, de Lucca MG et al - O rápido declínio da concentração sérica de proteína C-reativa na fase inicial da sepse é preditivo de boa evolução. RBTI, 2005;17:104-107.

36. Yentis SM, Soni N, Sheldon J - C-reactive protein as an indicator of resolution of sepsis in the intensive care unit. Intensive Care Med, 1995;21:602-605.

37. Ridker PM, Hennekens $\mathrm{CH}$, Buring JE et al - C-reactive protein and other markers of inflammation in the prediction of cardiovascular disease in women. N Engl J Med, 2000;342:836-843.

38. Kushner I - C-reactive protein in rheumatology. Arthritis Rheum, 1991;34:1065-1068

39. Soares AJC, David CMN - A avaliação do comportamento da proteína C-reativa em pacientes com sepse na UTI. RBTI, 2003;14:156-165.
40. Ugarte H, Silva E, Mercan D et al - Procalcitonin used as a marker of infection in the intensive care unit. Crit Care Med, 1999;27:498-504.

41. Lobo SM, Lobo FR, Bota DP et al - C-reactive protein levels correlate with mortality and organ failure in critically ill patients. Chest, 2003;123:20432049.

42. Tilg H, Nordberg J, Vogel W et al - Circulating serum levels of interleukin 6 and C-reactive protein after liver transplantation. Transplantation, 1992;54:142-146.

43. Schots R, Kaufman L, Van Riet I et al - Monitoring of C-reactive protein after allogeneic bone marrow transplantation identifies patients at risk of severe transplant-related complications and mortality. Bone Marrow Transplant, 1988;22:79-85.

44. Cox ML, Rudd AG, Gallimore R et al - Real-time measurement of serum C-reactive protein in the management of infection in the elderly. Age Ageing, 1986;15:257-266.

45. Presterl $\mathrm{E}$, Staudinger $\mathrm{T}$, Pettermann $\mathrm{M}$ et al - Cytokine profile and correlation to the APACHE III and MPM II scores in patients with sepsis. Am J Respir Crit Care Med, 1997;156:825-832.

46. Chiesa C, Panero A, Rossi $\mathrm{N}$ et al - Reliability of procalcitonin concentrations for the diagnosis of sepsis in critically ill neonates. Clin Infect Dis, 1998;26:664-672.

47. Wanner GA, Keel M, Steckholzer $U$ et al - Relationship between procalcitonin plasma levels and severity of injury, sepsis, organ failure, and mortality in injured patients. Crit Care Med, 2000;28:950-957.

48. Stucker F, Herrmann F, Graf JD et al - Procalcitonin and infection in elderly patients. J Am Geriatr Soc, 2005;53:1392-1395.

49. Christ-Crain M, Stolz D, Bingisser R et al - Procalcitonin Guidance of Antibiotic Therapy in Community-acquired Pneumonia: A Randomized Trial. Am J Respir Crit Care Med, 2006;174:84-93.

50. Viallon A, Guyomarc'h P, Guyomarc'h S et al - Decrease in serum procalcitonin levels over time during treatment of acute bacterial meningitis. Crit Care, 2005;9:R344-R350.

51. Meisner M, Adina H, Schmidt J - Correlation of procalcitonin and C-reactive protein to inflammation, complications, and outcome during the intensive care unit course of multiple-trauma patients. Crit Care, 2006;10: R1.

52. Meisner M, Tschaikowsky K, Hutzler A et al - Postoperative plasma concentrations of procalcitonin after different types of surgery. Intensive Care Med, 1998;24:680-684. 